Web Site: https://jmed.utq.edu.iq

ISSN (Print):1992-92 18, ISSN (Online):1992-92 18

Email:utjmed@utq.edu.iq

DOI: https://doi.org/10.32792/utq/utjmed/19/1/14

\title{
The Determination of Antibiotic Resistance of Burn Patients at Al-Imam Al-Hussein Hospital in Thi-Qar Province - Iraq
}

\author{
Hind Abdallah Salih \\ Collage of Science, University of Thi-Qar
}

\begin{abstract}
:
In the case of burned infections, the current study aims to identify and study the antimicrobial susceptibility of bacterial isolates. Between October 2012 to June 2013, 90 burn swabs were obtained between patients and 42 environment swabs who had both-sex bacterial burn disease admitted to the Al-Imam Al-Hussein hospital. Enterobacter spp. (25.6\%) has originate to be the most public isovlate followed by Staphylococcus epidrmiditis (17.8\%), Pseudomonas aeruginosa ( 12.2\%), Acinetobacter baumannii ( 11.1\%), Aeromonas hydrophila ( 5.6\%), while (3.33\%) for each from Klebsiella pneumonia, E . coli, Streptococcus spp. and Citrobacter spp. , (2.22\%) for each from Photobacter dansela, Proteus mirabilis, Lactobacillus spp. and Pantoea spp. finally (1.1\%) for each from Bacillus spp., Staphylococcus aureus, Flavinous oryzihabitans, Morganella morganii and Burkholderia cepacia . Bacterial isolates were tested for antimicrobial susceptibility against 10 antibiotics, where Levofloxacin was shown to become the most effective medicine to most Gramnegative and Gram-positive isolates led by Gentamicin, whereas Cephalothin and Ceftriaxone are extremely resistant (100\%).
\end{abstract}


Web Site: https://jmed.utq.edu.iq ISSN (Print):1992-92 18, ISSN (Online):1992-92 18

Email:utjmed@utq.edu.iq DOI: https://doi.org/10.32792/utq/utjmed/19/1/14

\section{Introduction}

Antibiotic resistance (ABR) has been described to be one of the major health troubles. Antibiotic resistance problems affect nearly every species of bacteria in which antibiotic therapy may be available. (Salih, 2008). It has been shown that antibiotic resistance rises through the treatment duration; hence, as long as a clinically active minimum (depending on the antibiotics involved and organism) was observed, by the medical community, using shorter antibiotic courses is likely to decrease resistant levels, reduce costs as well as achieve better results leading to less risks such as diarrhea and Clostridium difficile infection ( $\mathrm{Li}$ et al., 2007). Rising resistance prevalence was confirmed in many pathogens in different regions of the world over the years, which include advanced countries (Byarugaba, 2005). That was related with altering microbic features, specific antibacterial use constraints, and technological and societal changes that improve drug-resistant organism transmission and development. Even though antibiotic confrontation was a natural phenomenon in biology, it is sometimes enhanced by adapting infectious agents to antimicrobial use in humans and by the widespread use of household disinfectants (Walsh, 2000). It's now believed that that use of antimicrobials is the most important factor responsible for increased antimicrobial resistance (Aar estrup et al., 2001; Byaarugaba, 2004).
Burning is among the most devastating and common types of trauma. Patients with severe heat trauma require extensive immediate

care to reduce mortality and morbidity (Church etal. 2006). The risk of burning injury contamination is correlated with the severity of burning and is consistent with reduced tolerance arising from mechanical integrity destruction of the skin and widespread immune suppression. (Agnihotri et al. 2001; Bowler et al. 2004). Burn patients were at large infection risk because of the burn injury nature, the burns immunocompromising effects, therapeutic procedures, intensive diagnostic and prolonged hospital stays (Lari and Alaghehbandan, 2000). After the initial trauma age, sepsis was the main complicating factor in burn injuries as well as it's predicted that sepsis are associated with about $75 \%$ of burned-related mortality, particularly in developing countries. Moreover, overcrowding in burning units is an important cause of crossinfection requiring frequent surveillance of bacterial species and their antimicrobial susceptibility, as significant changes in these information the correlate with changes in medical management with respect to the choice of medication for therapy (Liwimbi and Komolafe, 2007).

\section{Methods and Materials}


Web Site: https://jmed.utq.edu.iq

ISSN (Print):1992-92 18, ISSN (Online):1992-92 18

Email:utjmed@utq.edu.iq

DOI: https://doi.org/10.32792/utq/utjmed/19/1/14

\section{Specimens Collection for Identification and Isolation:}

One hundred -fifty isolates are collected from burns unit, (108) swabs from patients including (90) swabs gave positive growth from different genuses and (18) swabs gave negative, (42) swabs from burns unit environments including (18) swabs gave positive growth and (24) swabs gave negative. Both those swabs have been transported and labeled within one hour to the lab, then splattered on MacConkey Agar, Blood Agar and Nutrient Agar. Both plates are protected for $24 \mathrm{hrs}$. at $37{ }^{\circ} \mathrm{C}$ in the incubator and then analyzed for isolation and bacterial growth. All isolates with differential colony morphology have been picked in a given plate. The isolates are purified after isolation and identified by a Gram stain test. With the help of Bergey's Manual for the bacterial isolates identification, a variety of biochemical experiments are carried out. The API $20 \mathrm{E}$ was also used to further validate the identification of different bacterial isolates (Biomurex) kit (Tassadaq et al., 2013). The unadulterated crops are sub-cultivated in nutrient agar slants and kept at $4 \mathrm{oC}$ in the fridge until the study was required.

\section{Antibiotic susceptibility:}

Disc diffusion approach was used to assess the resistance to the study isolates (Bauer etal., 1966). The antibiotic used in the analysis (content per disc) are Ax: Amoxycillin $(25 \mu \mathrm{g})$; TE: Tetracycline $(30 \mu \mathrm{g})$; NA:
Nalidixic acid (30 $\mu \mathrm{g})$; Ak: Amikacin $(30 \mu \mathrm{g})$; CRO: Ceftriaxone $(30 \mu \mathrm{g})$; CN: Gentamicin $(10 \mu \mathrm{g})$; KF: Cephalothin $\quad(30 \mu \mathrm{g})$; CAZ: Ceftazidime $\quad(30 \mu \mathrm{g}) ; \quad$ CIP: Ciprofloxacin $(5 \quad \mu g)$; LEV: Levofloxacin $(5 \mu \mathrm{g})$. Bioanalysis, Turkey, bought the antibiotic discs. Results have been recorded as for (CLSI, 2007).

\section{Results}

Out of 150 swabs, 90 clinical isolates, $23 / 90 \quad(25 \%)$ were gave Enterobacter spp.16/90 (17.8\%) were gave Staphylococcus epidrmiditis . 11/90 (12.2\%) were gave Pseudomonas aeruginosa . 10/90 (11.1\%) were gave Acinetobacter baumannii . 5/90 (5.6\%) were gave Aeromonas hydrophila . 3/90 (3.33\%) were gave each from Klebsiella pneumonia, E . coli, Streptococcus spp. and Citrobacter spp. 2/90 (2.22\%) were gave each from Photobacter dansela , Proteus mirabilis, Lactobacillus spp. and Pantoea spp. $1 / 90(1.1 \%)$ were gave each from Bacillus spp., Staphylococcus aureus, Flavinous oryzihabitans, Morganella morganii and Burkholderia cepacia. As in table (1) . 18 environmental isolates, 3/18 (16.6\%) were gave each from Bordetella spp. , Pantoea spp. , Enterobacter spp. and Pseudomonas aeruginosa . 1/18 (5.5\%) were gave each from Klebsilla spp. , Lactobacillus spp., , Staphylococcus epidrmiditis , Citrobacter spp., Pseudomonas fluorescence and Bacillus spp. as in table (2). Both isolate evolved on nutrient agar, blood 
Web Site: https://jmed.utq.edu.iq ISSN (Print):1992-92 18, ISSN (Online):1992-92 18

Email:utjmed@utq.edu.iq DOI: https://doi.org/10.32792/utq/utjmed/19/1/14

agar, and MacConkey agar to vary from Gram negative to Gram positive as well as Gram staining, catalase test,
IMVC test, and motility. API $20 \mathrm{E}$ system verified the classification of the isolates.

Table 1: Number and percentage of clinical samples

\begin{tabular}{|c|c|c|c|}
\hline Bacteria & No & $\%$ & Type \\
\hline Klebsiella pneumonia & 3 & 3.33 & Gram negative \\
\hline Acinetobacter baumannii & 10 & 11.1 & Gram negative \\
\hline Photobacter dansela & 2 & 2.22 & Gram negative \\
\hline Proteus mirabilis & 2 & 2.22 & Gram negative \\
\hline Pseudomonas aeruginosa & 11 & 12.2 & Gram negative \\
\hline E. coli & 3 & 3.33 & Gram negative \\
\hline Enterobacter spp. & 23 & 25.6 & Gram negative \\
\hline Pantoeaspp. & 2 & 2.22 & Gram negative \\
\hline Staphylococcus aureus & 1 & 1.1 & Gram negative \\
\hline Flavinous oryzihabitans & 1 & 1.1 & Gram negative \\
\hline Citrobacter spp. & 3 & 3.33 & Gram negative \\
\hline Aeromonas hydrophila & 5 & 5.6 & Gram negative \\
\hline Morrganella morrganii & 1 & 1.1 & Gram negative \\
\hline Burkholderiia cepaciia & 1 & 1.1 & Gram negative \\
\hline Staphylococcus epidrmiditis & 16 & 17.8 & Gram negative \\
\hline Lactobacillus spp. & 2 & 2.22 & Gram negative \\
\hline Bacillus spp. & 1 & 1.1 & Gram negative \\
\hline Streptococcus spp. & 3 & 3.33 & Gram negative \\
\hline Total & 90 & 100 & \\
\hline
\end{tabular}

Table 2: Number and percentage of environmental samples

\begin{tabular}{|c|c|c|c|}
\hline Swab Site & Swabs number & Bacteria & No. \\
\hline \multirow[t]{8}{*}{ Bed of patient } & \multirow[t]{8}{*}{20} & Bordetella spp. & 3 \\
\hline & & Pantoea spp. & 3 \\
\hline & & Klebsilla spp. & 1 \\
\hline & & Lactobacillus spp. & 1 \\
\hline & & Enterobacter spp. & 1 \\
\hline & & $\begin{array}{c}\text { Staphylococcus } \\
\text { epidrmiditis }\end{array}$ & 1 \\
\hline & & Citrobacter spp. & 1 \\
\hline & & $\begin{array}{c}\text { Pseudomonas } \\
\text { aeruginosa }\end{array}$ & 1 \\
\hline $\begin{array}{c}\text { Transport Vehicle of } \\
\text { patients }\end{array}$ & 5 & $\begin{array}{l}\text { Pseudomonas } \\
\text { areuginosa }\end{array}$ & 1 \\
\hline \multirow[t]{2}{*}{ Sinks } & \multirow[t]{2}{*}{8} & Enterobacter spp. & 1 \\
\hline & & $\begin{array}{c}\text { Pseudomonas } \\
\text { aeruginosa }\end{array}$ & 1 \\
\hline \multirow[t]{2}{*}{ Patients room floor } & \multirow[t]{2}{*}{4} & Enterobacter spp. & 1 \\
\hline & & $\begin{array}{l}\text { Pseudomonas } \\
\text { fluorescence }\end{array}$ & 1 \\
\hline Vehicle of the bandaging & 5 & Bacillus spp. & 1 \\
\hline
\end{tabular}


Web Site: https://jmed.utq.edu.iq ISSN (Print):1992-92 18, ISSN (Online):1992-92 18

Email:utjmed@utq.edu.iq DOI: https://doi.org/10.32792/utq/utjmed/19/1/14

\section{Antibiotic susceptibility}

During this study the sensitivity of 108 bacterial specimens to 10 anti-microbial agents from different classes were identified using Kirby-Bauer disk diffusion system Bauer et al., 1966. Table (3) indicates that $100 \%$ of isolations are immune to ceftriaxone and cephalothin, 98\% were resistant to amoxicillin, ceftazidime and tetracycline, $96.3 \%$ are resistance to nalidixic acid, $81.5 \%$ are resistance to amikacin, $77 \%$ are resistance to ciprofloxacin, as well as $74 \%$ are resistance to levofloxacin $(55.6 \%)$.

Table (3): percentage of isolate resistance to antibiotics as per CLSI 2007. ( $\mathrm{N}=108$ )

\section{Madam President,}

\begin{tabular}{|c|c|c|c|c|}
\hline \multirow[t]{2}{*}{ Antibiotic Type } & \multicolumn{2}{|c|}{$\begin{array}{c}\text { No. }(\%) \text { of Resistant } \\
\text { Isolates }\end{array}$} & \multicolumn{2}{|c|}{$\begin{array}{c}\text { No. }(\%) \text { of Sensitive } \\
\text { Isolates }\end{array}$} \\
\hline & No. & $\%$ & No. & $\%$ \\
\hline Amikacin & 88 & 81.5 & 20 & 18.5 \\
\hline Amoxicillin & 106 & 98 & 2 & 2 \\
\hline Ceftazidime & 106 & 98 & 2 & 2 \\
\hline Ceftriaxone $\quad$ (CRO) & 108 & 100 & 0 & 0 \\
\hline Cephalothin & 108 & 100 & 0 & 0 \\
\hline Ciprofloxacin $\quad$ (CIP) & 83 & 77 & 25 & 23 \\
\hline Gentamicin & 80 & 74 & 28 & 26 \\
\hline Levofloxacin $\quad$ (LEV) & 60 & 55.6 & 48 & 44.4 \\
\hline Nalidixic acid $\quad$ (NA) & 104 & 96.3 & 4 & 3.7 \\
\hline Tetracycline & 106 & 98 & 2 & 2 \\
\hline
\end{tabular}

\section{Discussion}

Alternatively, resistance may arise through mutation or DNA transfer in previously susceptible organisms (David, 2003). Resistance may arise from alteration of an antibacterial target or operational bypass of that target, or impermeability, efflux, or enzymatic inactivation may be conditional. It may be immune to all representatives of a

genus. The resistance shape of microorganisms was evolving due to the antibiotics widespread use, specifically in improving countries, as demonstrated by increasing presence of antibiotic resistance in bacterial 
Web Site: https://jmed.utq.edu.iq ISSN (Print):1992-92 18, ISSN (Online):1992-92 18

DOI: https://doi.org/10.32792/utq/utjmed/19/1/14

\section{Email:utjmed@utq.edu.iq}

populations (Farra, 1985; O'Brien, 1986). Ciprofloxacin, amikacin, nalidixic acid, tetracycline, ceftazidime, amoxicillin, cephalothin and high resistance against ceftriaxone has been shown in this study. while the resistance lower percentage was for levofloxacin . These results are according to (Rezaei et al., 2011).

Bacterial infection remains a critically important concern for burn patients following advancements in topical and parenteral antimicrobial treatment. A defective immune system, moist wounds and necrotic, gastrointestinal system transduction of infectious agents and severe invasive diagnostic, prolonged hospitalization and bacterial colonization and therapeutic procedures all relate to disease (Macedo and Santos, 2006). For patients and contamination of the hospital environment, we studied the evaluated bacterial resistance to antibiotics. Our findings showed that the gram-negative entity isolation level is more than grampositive, the findings are dependable with those stated by (Kehinde etal., 2004; Muhammad etal., 2011). Enterobacter spp was the most widespread pathogen isolated from burn wounds. $(25.6 \%)$ and, in accordance with other reports, Staphylococcus epidrmiditis (17.8) (Ozumba and Jiburum, 2000; Kaushik etal., 2001; Komolafe etal., 2003). There has been a direct relationship regarding antibiotic use and the proliferation of antibiotic-resistant bacteria in numerous studies (McGowan, 1983; Ringertz and Kronvall, 1987; Moller, 1989 and Mouton etal., 1990). Studies also suggest that decreasing antibiotic use may reduce the frequency of bacteria resistant to antibiotics (McGowan, 1983; Ballow and Schentag, 1992). The focus has been on reducing inappropriate uses in reducing antibiotic use.

\section{References}

Aarestrup, F. M. ; Seyfarth, A. M. ; Emborg, H. D. ; Pedersen, K. ; Hendriksen, R. S. and Bager, F.( 2001) . Effect of abolishment of the use of antimicrobial agents for growth promotion on occurrence of antimicrobial resistance in fecal enterococci from food animals in Denmark. Antimicrob Agents Chemother., 45: 2054-2059.

Agnihotri, N. ; Gupta, V. and Joshi, R. M. (2004) . Aerobic bacterial isolates from burn wound infections and their antibiogram, a five-year study. Burns 30:241-243.

Ballow, C.H., and Schentag, J.J. (1992) . Trends in antibiotic utilization and bacterial resistance (Report of the National Nosocomial Resistance Surveillance Group). Diagn Microbiol Infect Dis., 15: 37-42. 
Web Site: https://jmed.utq.edu.iq

ISSN (Print):1992-92 18, ISSN (Online):1992-92 18

DOI: https://doi.org/10.32792/utq/utjmed/19/1/14

Email:utjmed@utq.edu.iq

Bauer, A. ; Kirby, W. ; Sherris, J. and Turtch, M. (1996) . Antibiotic susceptibility testing by standardized single disk method. Am J Clin Path., 43: 493-96.

Bowler, P.G. ; Duerden, B.I. and Armstrong, D.G. (2001). Wound microbiology and associated approaches to wound management. Clin Microbiol Rev., 14:244-269.

Byarugaba, D. K. (2004) . A view on antmicrobial resistance in developing countries and responsible risk factors. Int J Antimicrob Agents., 24: 105-110.

Church, D. ; Elsayed, S. ; Reid, O. Winston, B. and Lindsay, R. (2006) . Burn wound infections. Clin Microbiol Rev., 19: 403-34.

CLSI: Clinical and Laboratory Standards Institute (2007). Performance Standards for antimicrobial susceptibility testing, seventeenth informational supplement, CLSI document M100-S17, Wayna, PA. USA.

David, M. L. (2003). Bacterial Resistance: Origins, Epidemiology, and Impact. Infect Dis Ther., $36: 11-23$.

Farrar, W.E. (1985). Antibiotic resistance in developing countries. J Inf Dis., 152 :1103-6.

Kaushik, R. ; Kumar, S. ; Sharma, R. and Lal, P. (2001). Bacteriology of burn wounds-the first 3 years in a new burn unit at the Medical College Chandigarh. Burns., 27: 595-597.

Kehinde, A. O. ; Ademola, S.A.; Okesola, A.O. and Oluwatosin, O. M. (2004). Pattern of bacterial pathogens in burn wound infections in Ibadan, Nigeria. Burns., 107: 348-355.

Komolafe, O. O. ; James, J. ; Kalongolera, L. and Makoka, M. (2003). Bacteriology of burns at the Queen Elizabeth Central Hospital, Blantyre, Malawi. Burns., 29: 235-238.

Lari, A. R. and Alaghehbandan, R.( 2000) . Nosocomial infections in an Iranian burn care center. Burns. 26: 737-40.

Li, J. Z. ; Winston, L. G. ; Moore, D. H. and Bent, S. (2007). "Efficacy of shortcourse antibiotic regimens for community-acquired pneumonia: a meta-analysis". Am. J. Med., 120 : 783-90.

Liwimbi, O. and Komolafe, I. ( 2007 ). Epidemiology and bacterial colonization of burn injuries in Blantyre, Malawi medical journal., 19: 25-27.

Macedo, J. L. and Santos, J.B. (2006). Nosocomial infections in a Brazilian Burn Unit. Burns., 32: 477-481. 
Web Site: https://jmed.utq.edu.iq ISSN (Print):1992-92 18, ISSN (Online):1992-92 18

DOI: https://doi.org/10.32792/utq/utjmed/19/1/14

\section{Email:utjmed@utq.edu.iq}

McGowan, J.E. (1983). Antimicrobial resistance in hospital organisms and its relation to antibiotic use. Rev Infect Dis., 5:1033-1048.

Mohammed, J. ; Alwan I. J. and Aseel, M. H. (2011). Bacterial isolation from burn wound infections and studying their antimicrobial susceptibility . Kufa Journal For Veterinary Medical Sciences., 2: 121-131.

Moller, J.K. (1989). Antimicrobial usage and microbial resistance in a university hospital during a seven-year period. J Antimicrob Chemother., 24:983-992.

Mouton, R.P.; Herman, J.; Simoons-Smit, A.M., Hoogkamp-Korstanje, J. A. ; Degener, J.E. and van, K. B. (1990). Correlations between consumption of antibiotics and methicillin resistance in coagulase negative staphylococci. $\mathrm{J}$ Antimicrob Chemother., 26:573-583.

O'Brien, T. F. (1986) . Resistance to antibiotics at medical centers in different parts of the world. J Antimicrob Chemother., 18 : 919-26.

Ozumba, U. C. and Jiburum, B.C. (2000). Bacteriology of burn wounds in Enugu, Nigeria. Burns. 26 : 178-80.

Rezaei, E. ; Safari, H. ; Naderinasab, M. and Aliakbarian, H. (2011). Common pathogens in burn wound and changes in their drug sensitivity. Burns. 37: 805-7.

Ringertz, S. and Kronvall, G. (1987) . Increased use of erythromycin causes resistance in Haemophilus influenzae. Scand J Infect Dis., 19:247-256.

Salih, S.S. (2008). Some bacteriological and molecular studies of P. aeruginosa isolated from different environments. M.Sc. Thesis, The higher Academy of Human and Science Studies. Baghdad, Iraq.

Tassadaq, H. ; Aneela, R. ; Shehzad, M. ; Iftikhar, A. ; Jafar, K. ; VeroniqueEdel, H. ; Kil, Y. K.and Muhammad, A. (2013). Biochemical characterization and identification of bacterial strains isolated from drinking water sources of Kohat, Pakistan. Afr J Microbiol Res., 7:1579-1590.

Walsh, C. (2000). Molecular mechanisms that confer antibacterial drug resistance. Nature., 406: 775-781. 
Web Site: https://jmed.utq.edu.iq

ISSN (Print):1992-92 18, ISSN (Online):1992-92 18

DOI: https://doi.org/10.32792/utq/utjmed/19/1/14
تحديد مقاومة المضادات في مرضى حروق مستشفى الامام

هند عبدالله صالح

كلية العلوم اقنم علوم العياة

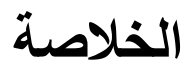

في حالة اصابات الحروق ، تهدف الدراسة الحالية إلى تحديد ودراسة قابلية العزلات البكتيرية لمضادات الميكروبات. بين

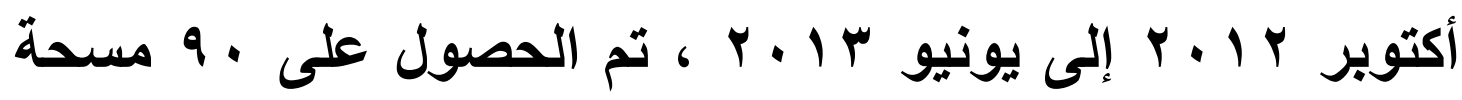
حروق بين المرضى و بـ مسحة بيئية من المصابين بمرض الحروق الجرثومي من الجنسين تم إدخالهم إلى مستثفى الإمام الحسين حيث تم الحصول على عدد من الاجناس البكتيرية وبنسب مختلفة. تم اختبار العزلات البكتيرية عن قابلية مضادات الميكروبات مقابل ، 1 مضادات حيوية ، حيث تبين أن الليفوفلوكساسين هو الدواء الأكثر فعالية لمعظم العزلات سالبة الجرام وإيجابية الجرام بقيادة الجنتاميسين ، بينما سيفالوثين وسيفترياكسون ذات مقاومة عالية ( . . 1\%). 